\title{
Seasonal food habits of the four-horned antelope (Tetracerus quadricornis de Blainville, 1816) in tropical deciduous forests of Aravalli mountain range, Rajasthan, Western India
}

\author{
Ramchandra Meghwal ${ }^{*}$ (i), Chhaya Bhatnagar(i) and Vijay Kumar Koli(D)
}

\begin{abstract}
Background: Feeding strategies assessment of endangered species during food limited seasons is important in order to understand their niche and advise effective habitat management steps. We assessed the four-horned antelope (Tetracerus quadricornis) seasonal diet from April 2014 to March 2015, in three wildlife sanctuaries in western India, namely, Sitamata, Kumbhalgarh, and Phulwari-ki-nal Wildlife Sanctuaries. Opportunistic focal animal sampling method was used in five $1 \mathrm{~km}$ paths in each sanctuary to take feeding observations. Each transect was walked three times a day (morning 06:00-10:00 h; mid-day 10:00-14:00 h; evening 15:00-18:00 h), 1 day a month, during 12 months, with a total of 540 surveys divided between 15 paths. The diet data was categorized into different plant categories.
\end{abstract}

Results: A total of 532 feeding records from 85 animal sightings were noted with a mean ( \pm SD) of $14.78 \pm 10.04$ feeding records/month. Feeding was observed on 63 plant species belonging to 23 families. The highest feeding records noted were on trees (60.91\%) in the diet followed by shrubs (20.49\%), grasses (16.92\%), forbs (1.50\%), and climbers (0.18\%) respectively. Most of the plant species consumed were from Fabaceae $(n=17)$ and Poaceae $(n=12)$ families. The overall browse-grass ratio was 83.08-16.92\% (88.02-11.98\% for Sitamata WLS; 82.11-17.89\% for Kumbhalgarh WLS; 79.10-20.90\% for Phulwari-ki-nal WLS). Leaves were the most consumed part of the plants (64.10\%), followed by dry fruit (16.55\%), fleshy fruit (13.34\%), flowers (2.82\%), buds (2.06\%), and twigs (1.13\%) respectively. Use of fleshy fruits, dry fruits, and trees showed significant seasonal dietary difference $(P<0.05)$ in all three sanctuaries.

Conclusions: Tetracerus quadricornis was found to consume more browse species than grasses. We recommend conservation and promotion of natural plant regeneration, in particular for the plant species that were the most consumed by four-horned antelope, namely, Aristida adscensionis, Dendrocalamus strictus, Dichrostachys cinerea, Acacia leucophloea, Butea monosperma, Helicteres isora, Ziziphus nummularia, and Ziziphus xylopyrus. Conservation of grassland patches, minimizing local pressure, and planning, construction, and maintenance of fire lines prior to timing of forest fires would help to protected T. quadricornis habitat in all three sanctuaries.

Keywords: Bovid, Diet, Four-horned antelope, Rajasthan, Browser, India

* Correspondence: ramchandramlsu@gmail.com

Department of Zoology, Aquatic Toxicology and Wildlife Research Lab,

Mohanlal Sukhadia University, Udaipur, Rajasthan 313001, India 


\section{Background}

The four-horned antelope (Tetracerus quadricornis de Blainville, 1816) or chowsingha is a solitary Asian herbivore bovid (17-22 kg adult weight, $55-64 \mathrm{~cm}$ height at the shoulder) endemic to peninsular India and Nepal (Leslie \& Sharma, 2009), living in hilly and undulating terrain (Baskaran, Kannan, Thiyagesan, \& Desai, 2011; Prater, 1980). It lives in isolated patches across tropical dry deciduous forest habitats (Krishna, Clyne, Krishnaswamy, \& Kumar, 2009; Pokharel, Ludwig, \& Storch, 2016; Sharma, Chundawat, Gruisen, \& Rahmani, 2013). Because of its elusive, cryptic, and shy nature, the species is extremely difficult to observe directly in the wild across its range. Only males show sexual dimorphism through the presence of four horns (Leslie \& Sharma, 2009). A number of ecological variables, i.e., water availability, temperature variation between seasons, tree species richness (Pokharel et al., 2016; Sharma et al., 2013), precipitation, elevation, slope, and anthropogenic disturbance (Pokharel et al., 2016), are expected to govern its spatial distribution, while the presence of an alien weed Lantana camara is found to be negatively correlated with its occurrence (Krishna, Krishnaswamy, \& Kumar, 2008). IUCN (Mallon, 2008) categorizes T. quadricornis as vulnerable due to small population, decreasing population trends, and habitat destruction which is primarily due to habitat clearance for farming. It is also included in Schedule I of Indian Wildlife Protection Act, which provides absolute protection of the species.

Effective conservation relies on detailed knowledge of species' ecological needs, food habits, and foraging ecology. Understanding the habitat ecology of species especially in relation to the plant community surrounding them is therefore essential. Diet knowledge and food plant species protection play a key role in species management, especially in situations where the species live in captivity or in its native habitat. The fecal analysis method is widely adopted to assess ungulate food habits (Baskaran et al., 2011) due to its advantage of being non-invasive. However, it is biased due to the different plants' digestibility (Anthony \& Smith, 1974), an efficient digestive system, and a high degree of ungulate mastication (Korschgen, 1971). There is very little information on T. quadricornis food habits. Few short time studies through direct field observation, cafeteria experiments (Sharma, Rahmani, \& Chundawat, 2009) and fecal analysis (Kunwar, Gaire, Pokharel, Baral, \& Thapa, 2016) find it both a grazer and a browser with a generalized feeding strategy. Our study therefore offers an opportunity to assess the seasonal variation in $T$. quadricornis food habit in its different and lesser-known area. This long-term direct observation will also provide reliable information that can be used for this species' entire range of conservation planning.

\section{Methods}

\section{Study area}

The study was conducted in three wildlife sanctuaries, namely, Sitamata, Kumbhalgarh, and Phulwari-ki-nal Wildlife Sanctuaries (WLS) situated in the Aravalli mountain ranges of Rajasthan, India (Fig. 1). Sitamata WLS (area of 423 square $\mathrm{km}$ ) forms the north-western limit of Teakbamboo forest in India. The sanctuary forest is dominated by dense dry deciduous forests followed by sparse dry deciduous forests and bamboo mixed forests. These vegetations are interspersed with perennial streams, water bodies, undulating mountains, deep gorges, and fine grooves of mixed woodlands. Also, there are dense groves of Mangifera indica (mango) and Madhuca indica (mahua) in centrally located valleys (Koli, Bhatnagar, \& Sharma, 2013). A total of 64 species of trees, 58 species of shrubs, 26 species of climbers, 92 species of forbs, and 48 species of grasses have been reported from the sanctuary (FES, 2010a). Kumbhalgarh WLS (area of 610 square $\mathrm{km}$ ) is located at the junction of the Thar Desert and Aravalli hills, with an elevation range of between $288 \mathrm{~m}$ and $1215 \mathrm{~m}$. The sanctuary has semi-arid vegetation with a mix of dry deciduous forest and grassy savanna along with some patchy thick perennial canopy corridors on the riparian. Few patches of forest are dominated by Anogeissus latifolia, Anogeissus pendula, Boswellia serrata, Lannea coromandelica, Wrightia tinctoria, Acacia senegal, Acacia catechu, Butea monosperma, and Ziziphus mauritiana (Champion \& Seth, 1968; FES, 2010b; Robbins, Chhangani, Rice, Trigosa, \& Mohnot, 2007). Phulwari-ki-nal WLS (area of 511 square $\mathrm{km}$ ) contained dense dry deciduous, semi-dry deciduous and moist deciduous forests. Dense dry deciduous forest is found on cliffs, foothills, and valley floor, while semi-dry deciduous forest, dominated by Boswellia serrata and Lannea coromandelica, and moist deciduous forest are respectively found from the top to middle slope, and along streams and rivers (Champion \& Seth, 1968). The area supports a total of 515 plant species, including 81 species of trees, 32 species of shrubs, 201 species of herb, and 53 species of grasses and others (FES, 2010c; Sharma, 2007).

The climate of the study areas is characterized by summer (March-June), monsoon (July-October), and winter (November-February) seasons. The maximum daily temperature ranges from $46^{\circ} \mathrm{C}$ in May to $25^{\circ} \mathrm{C}$ in January, while the minimum night temperature ranges from $26^{\circ} \mathrm{C}$ in July to $5^{\circ} \mathrm{C}$ in January (Meghwal, Bhatnagar, \& Koli, 2018). The most common mammals found in these regions include leopard (Panthera pardus), striped hyena (Hyaena hyaena), jackal (Canis aureus), indian wolf (Canis lupus pallipes), indian fox (Vulpes bengalensis), chinkara (Gazella gazella), sambar (Rusa unicolor), blue bull (Boselaphus tragocamelus), southern plains gray langur (Semnopithecus dussumieri), and sloth bear (Melursus ursinus) (FES, 2010a, 2010b, 2010c; Koli \& Bhatnagar, 2011; Meghwal, Sen, \& Bhatnagar, 2014; Sharma, 2007). 


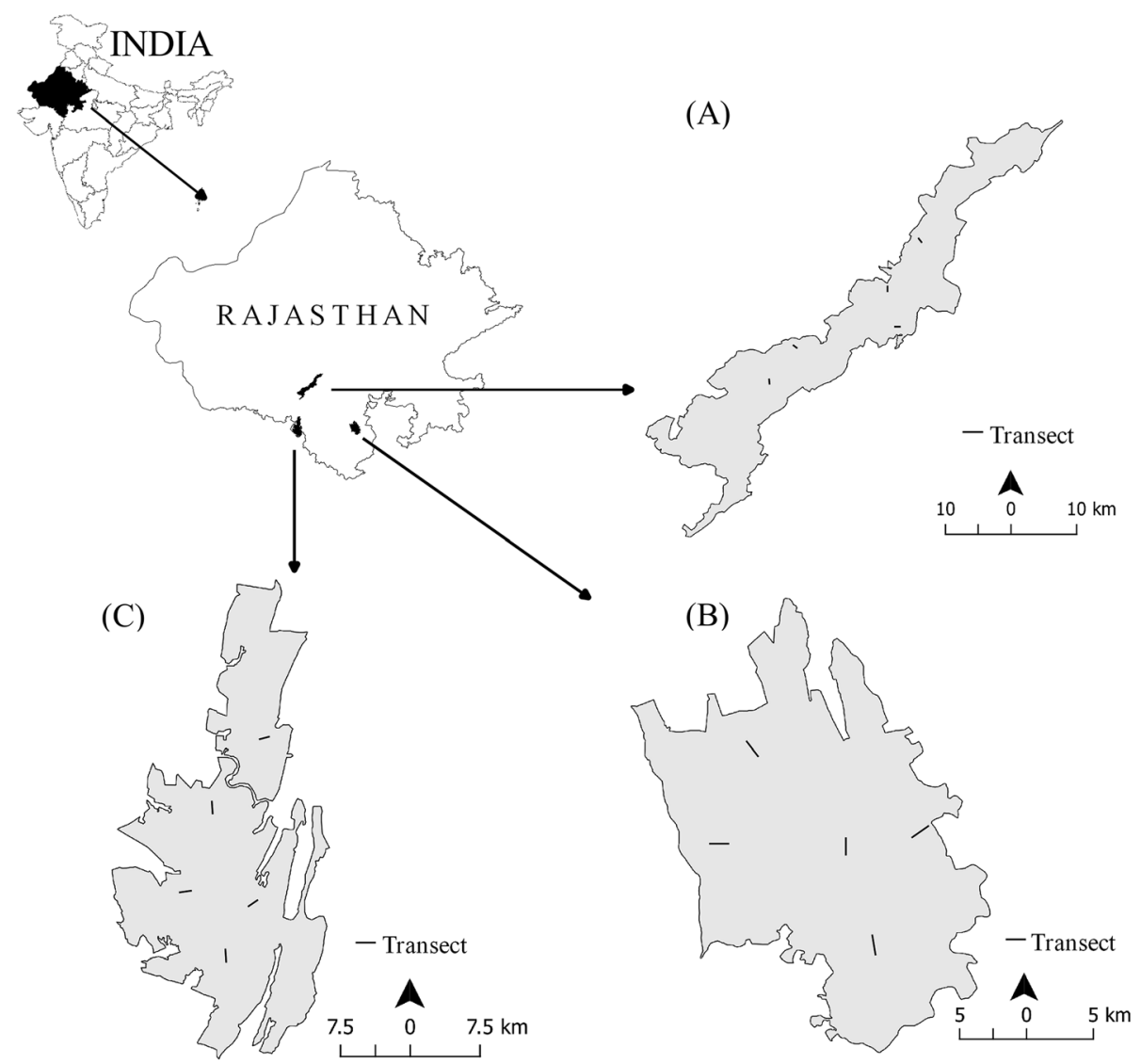

Fig. 1 Location of the study area, i.e., Kumbhalgarh Wildlife Sanctuary (a), Sitamata Wildlife Sanctuary (b), and Phulwari-ki-nal Wildlife Sanctuary (c) in southern Rajasthan, India

\section{Field observations}

The study was conducted from April 2014 to March 2015. First, thorough surveys were carried out on foot or on motorcycle in the study area to identify areas with a high probability of $T$. quadricornis presence. Then in each sanctuary, five $1 \mathrm{~km}$ paths were selected to maximize $T$. quadricornis encounters to meet out our study purpose as well as further observations. Each transect was walked three times a day (morning 06:00-10:00 h; mid-day 10:0014:00 h; evening 15:00-18:00 h.), 1 day a month, during 12 months, with a total of 540 surveys divided between 15 paths. During each season, these paths were walked at a pace of $1 \mathrm{~km} / \mathrm{h}$ to locate active animals (i.e., those not bedded). All sightings were considered as independent observations. Since no individual was radio tagged, and due to the elusive tactics of escape, small size, and shy nature of T. quadricornis, we used opportunistic focal animal sampling method (Altmann, 1974) to take feeding observation in the wild. When an animal was spotted, we observed it using binoculars (Olympus $10 \times 50$ DPS I) without interference or as long as it accepts our presence. Every time an individual was seen eating on a plant species, it was noted as one feeding record. The plant species and the part of the plant that was eaten (e.g., leaves, twigs, flower, fleshy fruits, dry fruit/pod) were noted on the spot during animal feeding. When identification was uncertain on the field, plants were collected and checked using literature the next day. We retained only confirmed observation on feeding records for further analysis.

\section{Statistical analysis}

The diet data were categorized into four plant categories (Kunwar et al., 2016), namely, (1) functional groups (grasses, forbs, shrubs, climbers, and trees), (2) specific taxonomic groups (monocot and dicot), (3) plant families, and (4) plant species. To determine if the T. quadricornis is browser or a grazer, monocot and dicot plants were assigned to grass and browse respectively (Kunwar et al., 2016; Shipley, 1999). The browse and grass ratio was expressed in percentage.

The relative frequency of a specific plant species or of part of the plant was calculated as number of records of feeding of that species or part/total number of feeding records on plants or parts $\times 100$ (Koli et al., 2013). The normality of the data was tested with KolomogorovSmirnov goodness of fit procedure. Hereafter, data was 
arcsine-square root transformed before analysis to produce a normal distribution. We first used one-way ANOVA to test if the number of sighted antelopes and number of feeding records were significantly different between the three sanctuaries. Then the same test was used separately at each sanctuary to analyze the dietary difference between the three seasons. Results were considered significant at $P<$ 0.05 level. All statistical analysis was performed in the GraphPad Prism statistical software (version 3.02).

\section{Results}

A total of 532 feeding records from 85 animal sightings were noted with an average $( \pm$ SD) $14.78 \pm 10.04$ feeding records/month (range 0-81) (Table 1). The number of sighted antelopes was not significantly different between the three sanctuaries $(F=3.08, P=0.06)$, but the number of feeding observations recorded was significantly different between sanctuaries ( $F=7.56, P=0.002)$ (Table 1$)$.

Overall, T. quadricornis feeding was observed on 63 plant species (56 in summer, 30 in monsoon, and 41 in winter seasons) belonged to 23 families (Table 5 in Appendix). Trees contributed to much of the diet (60.91\%) followed by shrubs (20.49\%), grasses (16.92\%), forbs (1.50\%), and climbers $(0.18 \%)$ respectively. The most commonly used plant species were Aristida adscensionis (Poaceae; grass), Dendrocalamus strictus (Poaceae; shrub), Dichrostachys cinerea (Fabaceae; shrub), Acacia leucophloea (Fabaceae; tree), Butea monosperma (Fabaceae; tree), Helicteres isora (Malvaceae; shrub), Ziziphus nummularia (Rhamnaceae; shrub), and Ziziphus xylopyrus (Rhamnaceae; tree). The highest number of plants in the diet was from the families of Fabaceae $(n=17)$ and Poaceae $(n=12)$ while the remaining families were less (range 1-4 plant species). The overall browse-grass ratio, all season and site combined, was 83.08-16.92\%. The ratio varied significantly $(F=4.94, P=0.02)$ between season, from $92.91-7.09 \%$ in summer to 59.09 $40.91 \%$ in monsoon. The difference was less significant $(F=1.18, P=0.28)$ between sites $(88.02-11.98 \%$ for Sitamata WLS; $82.11-17.89 \%$ for Kumbhalgarh WLS; 79.1020.90\% for Phulwari-ki-nal WLS).

Six different plant parts were seasonally consumed by $T$. quadricornis in various accounts (Fig. 2). Leaves were consumed most (64.10\%) year round, followed by dry fruits (16.55\%), fleshy fruits (13.34\%), flowers $(2.82 \%)$, buds $(2.06 \%)$, and twigs $(1.13 \%)$ respectively. The use of different plant parts in all three sanctuaries showed insignificant seasonal differences (Sitamata WLS, $F=1.18, P=0.28$; Kumbhalgarh WLS, $F=0.68, P=0.54$; Phulwari-ki-nal WLS, $F=99, P=0.37)$. Overall, leaves were eaten the highest in the winter season while lowest in summer season. Dry fruit intake was the highest in summer season. Fleshy fruits were accounted more or less equal in summer and monsoon seasons but less used in winter season (Fig. 2). Variations in the use of different plant parts at the study sites are presented in Table 2.

Overall, various functional groupings of plants used by T. quadricornis showed significant seasonal dietary variation ( $F=0.94, P=0.042$ ) (Fig. 3 ). Trees added the most to the diet throughout the year, while grass was lowest in the summer diet but increased in the monsoon diet (Fig. 3). Dicot plants contributed more than monocot plants in the diet. The use of monocot plants slightly increased during the monsoon season (Fig. 4). Functional and taxonomic plant groups' variation in the diet at the study sites is shown in Table 3.

Table 1 Number of sighted four-horned antelope (T. quadricornis) and number of feeding records noted in three wildlife sanctuaries (WLS) of southern Rajasthan, India, during the study period

\begin{tabular}{|c|c|c|c|c|c|c|}
\hline \multirow[t]{2}{*}{ Month } & \multicolumn{2}{|l|}{ Sitamata WLS } & \multicolumn{2}{|l|}{ Kumbhalgarh WLS } & \multicolumn{2}{|l|}{ Phulwari-ki-nal WLS } \\
\hline & Number of sighted animal & Feeding record & Number of sighted animal & Feeding record & Number of sighted animal & $\begin{array}{l}\text { Feeding } \\
\text { record }\end{array}$ \\
\hline January & 2 & 14 & 3 & 20 & 0 & 0 \\
\hline February & 4 & 16 & 2 & 17 & 0 & 0 \\
\hline March & 4 & 16 & 4 & 21 & 3 & 10 \\
\hline April & 5 & 20 & 6 & 36 & 1 & 3 \\
\hline May & 4 & 29 & 8 & 40 & 3 & 12 \\
\hline June & 3 & 18 & 6 & 22 & 3 & 15 \\
\hline July & 2 & 15 & 2 & 25 & 2 & 12 \\
\hline August & 0 & 0 & 0 & 0 & 0 & 0 \\
\hline September & 2 & 14 & 1 & 15 & 0 & 0 \\
\hline October & 1 & 11 & 2 & 20 & 1 & 7 \\
\hline November & 2 & 24 & 2 & 25 & 2 & 11 \\
\hline December & 1 & 9 & 3 & 26 & 1 & 9 \\
\hline Total & 30 & 186 & 39 & 267 & 16 & 79 \\
\hline
\end{tabular}



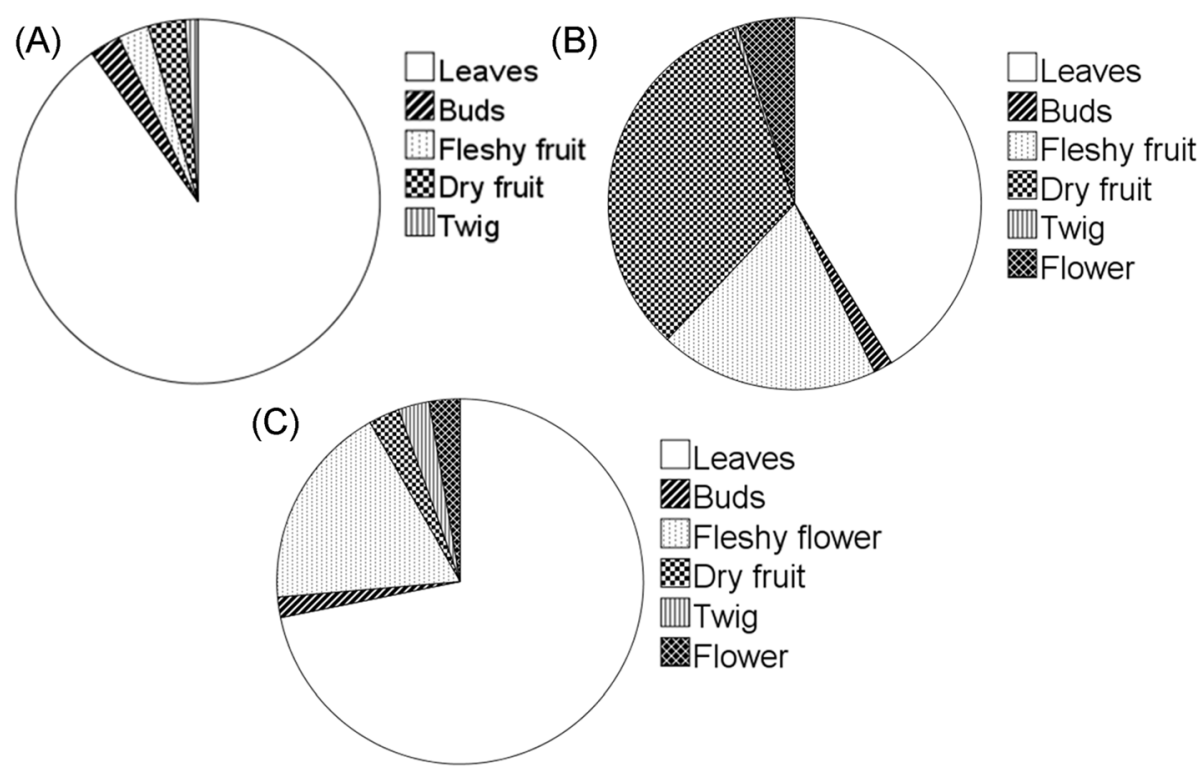

Fig. 2 Seasonal composition (\%) of different plant parts in the four-horned antelope (T. quadricornis) diet in the tropical deciduous forests of southern Rajasthan, India (a, winter; b, summer; c, monsoon)

\section{Discussion}

In our study, T. quadricornis consumed more browse species (overall 83.08\%) than grasses (overall 16.92\%), even during monsoon season (when grass is more available), when the average ration reached 59.09$41.91 \%$. Trees contributed the most $(60.91 \%)$ to the diet, followed by shrubs (20.49\%), grasses (16.92\%), forbs $(1.50 \%)$, and climbers $(0.18 \%)$. Our study result corresponds to the studies done by Kunwar et al. (2016) and Oli et al. (2018) in Nepal. On the other hand, Baskaran et al. (2011) found that grasses were the major part (28.6\%) of T. quadricornis diet followed by trees (8.18\%), shrubs (5.56\%), herbs (9.61\%), and unidentified (48.07\%), while Kunwar

Table 2 Comparison of plant parts consumption between seasons in each of the three wildlife sanctuaries (WLS)

\begin{tabular}{llll}
\hline Plant parts & Sitamata WLS & Kumnhalgarh WLS & $\begin{array}{l}\text { Phulwari-ki- } \\
\text { nal WLS }\end{array}$ \\
\hline Leaves & $F=3.47$ & $F=1.00$ & $F=0.23$ \\
& $P=0.90$ & $P=0.42$ & $P=0.79$ \\
Dry fruit & $F=4.17$ & $F=6.88$ & $F=5.38$ \\
& $P=0.01^{*}$ & $P=0.01^{*}$ & $P<0.01^{*}$ \\
Fleshy fruit & $F=3.34$ & $F=2.28$ & $F=8.81$ \\
& $P=0.04^{*}$ & $P=0.03^{*}$ & $P=0.01^{*}$ \\
Buds & $F=0.51$ & $F=0.38$ & $F=2.44$ \\
Flowers & $P=0.62$ & $P=0.43$ & $P=0.80$ \\
& $F=1.01$ & $F=2.44$ & $F=1.08$ \\
Twigs & $P=0.43$ & $P=0.80$ & $P=0.39$ \\
& $F=1.29$ & $F=1.19$ & $F=0.74$ \\
& $P=0.29$ & $P=0.28$ & $P=0.39$
\end{tabular}

Number of feeding record is significantly different between seasons if $P$ $<0.05^{*}$ et al. (2016) recorded trees as the highest proportion $(25.87 \%)$ of diet followed by shrubs (21.3\%), forbs $(18.2 \%)$, grasses $(10.5 \%)$, climbers $(4.36 \%)$, and unidentified (19.77\%) (Table 4). The disparity in outcomes could be attributed to the difference in methodologies and periods of study used (Table 4). Our study was entirely based on direct observations, while Baskaran et al. (2011), Kunwar et al. (2016), and Oli et al. (2018) made observations using microhistological techniques via pellet examination (indirect method). Their results could be biased by a large proportion of unidentified plant material. Few cafeteria experiments (Berwick, 1974; Sharma et al., 2009) also support the dominance of browse in the diet of $T$. quadricornis.

Browse diet of T. quadricornis could be explained by four possible reasons in our study area. Firstly, the current study area falls under semi-arid zone of state and remains dry during most of the year. Therefore, during the dry season of tropical forests, grass species become too coarse and less nutritious than the wet season (Baskaran, 1998; Baskaran et al., 2011; Sukumar, 1989). This corresponds to the results obtained for the browsegrass ratio obtained in summer and monsoon. Secondly, browsing is usually found to be rich in protein, and its chemical composition varies less compared to grasses in seasons (Lukhele \& Van Ryssen, 2003). Trees also extract nutrients from deep soil layers using a deep root system, which is inaccessible to shallow-rooted plants like grasses and herbaceous plants. Thus, browse provides a good source of nutrients for wild ungulates (Mbatha \& Bakare, 2018; Ngwa, Nsahlai, \& Iji, 2004), 

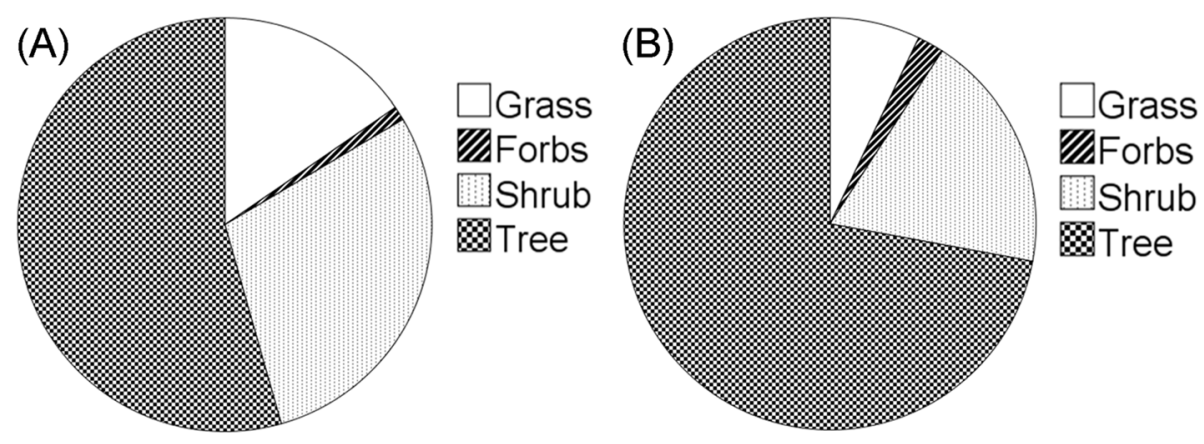

(C)

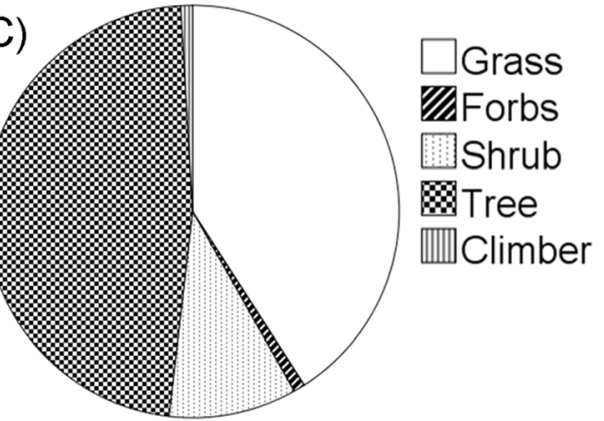

Fig. 3 Seasonal composition (\%) of different plant categories in the four-horned antelope (T. quadricornis) diet in the tropical deciduous forests of southern Rajasthan, India (a, winter; b, summer; $\mathbf{c}$, monsoon)
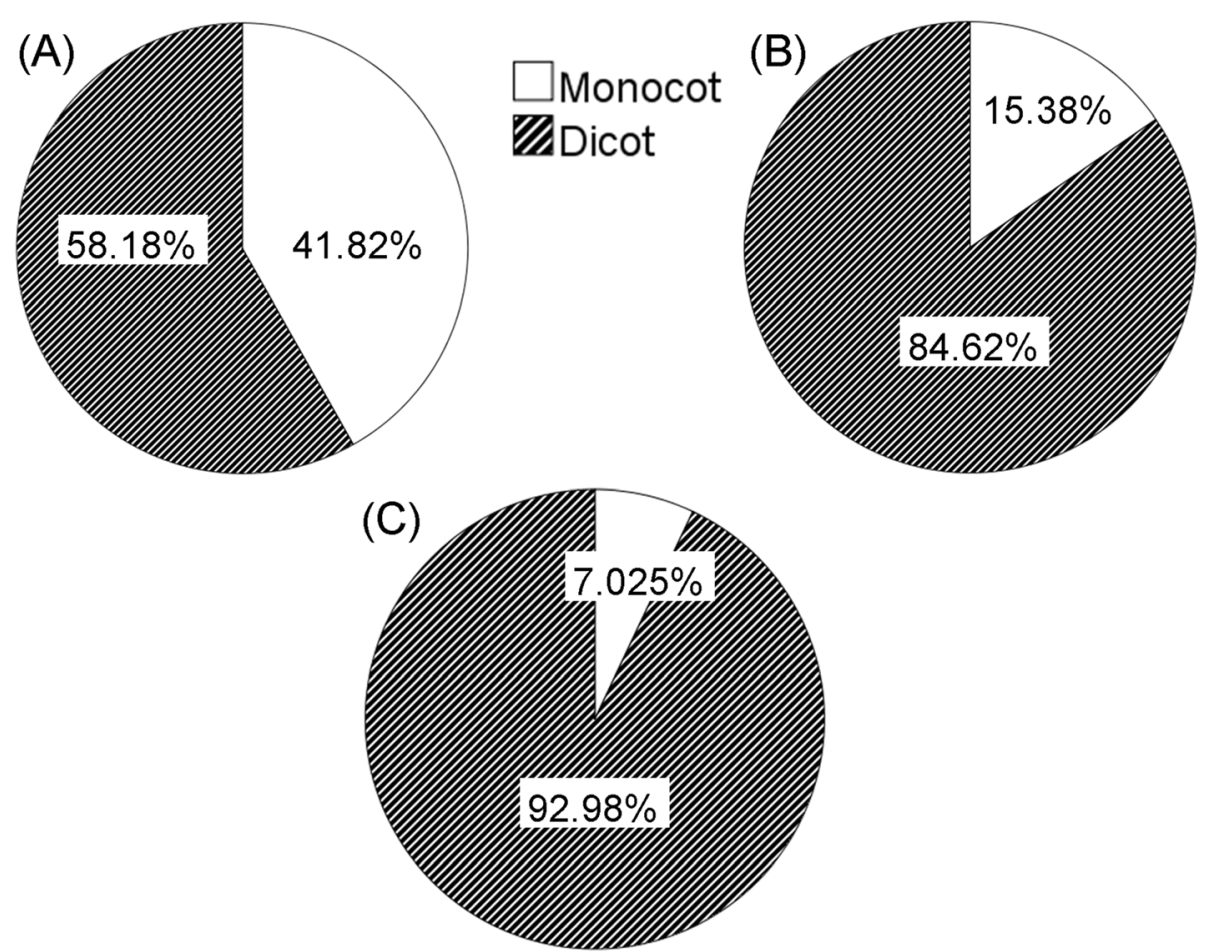

Fig. 4 Seasonal composition (\%) of monocot and dicot plants in the four-horned antelope (T. quadricornis) diet in the tropical deciduous forests of southern Rajasthan, India (a, winter; b, summer; c, monsoon) 
Table 3 Comparison of monocot and dicot plant consumption between seasons in each of three wildlife sanctuaries (WLS)

\begin{tabular}{|c|c|c|c|c|}
\hline Plants group & Plant category & Sitamata WLS & Kumnhalgarh WLS & Phulwari-ki-nal WLS \\
\hline \multirow[t]{2}{*}{ Taxonomic } & Monocot & $\begin{array}{l}F=0.93 \\
P=0.44\end{array}$ & $\begin{array}{l}F=2.10 \\
P=0.13\end{array}$ & $\begin{array}{l}F=1.13 \\
P=0.34\end{array}$ \\
\hline & Dicot & $\begin{array}{l}F=6.20 \\
P=0.003^{*}\end{array}$ & $\begin{array}{l}F=3.47 \\
P=0.04^{*}\end{array}$ & $\begin{array}{l}F=0.015 \\
P=0.98\end{array}$ \\
\hline \multirow[t]{5}{*}{ Functional } & Grasses & $\begin{array}{l}F=1.30 \\
P=0.29\end{array}$ & $\begin{array}{l}F=0.23 \\
P=0.63\end{array}$ & $\begin{array}{l}F=0.001 \\
P=0.97\end{array}$ \\
\hline & Forbs & $\begin{array}{l}F=0.26 \\
P=0.60\end{array}$ & $\begin{array}{l}F=0.51 \\
P=0.61\end{array}$ & $\begin{array}{l}F=0.46 \\
P=0.72\end{array}$ \\
\hline & Climber & $\begin{array}{l}F=2.72 \\
P=0.10\end{array}$ & $\begin{array}{l}F=2.76 \\
P=0.11\end{array}$ & $\begin{array}{l}F=1.26 \\
P=0.28\end{array}$ \\
\hline & Shrubs & $\begin{array}{l}F=1.62 \\
P=0.20\end{array}$ & $\begin{array}{l}F=3.06 \\
P=0.09\end{array}$ & $\begin{array}{l}F=2.61 \\
P=0.06\end{array}$ \\
\hline & Trees & $\begin{array}{l}F=11.71 \\
P=0.008^{*}\end{array}$ & $\begin{array}{l}F=32.4 \\
P<0.001^{*}\end{array}$ & $\begin{array}{l}F=72.25 \\
P=0.01^{*}\end{array}$ \\
\hline
\end{tabular}

Number of feeding record is significantly different between seasons if $P<0.05^{*}$

but it also contains more secondary metabolites (condensed tannins, alkaloids, terpenes) than grasses, reducing digestibility (Robbins, 1993; Robbins, Spalinger, \& Van Hoven, 1995). Nonetheless, some secondary metabolites such as tannins can also mitigate iron overload disorder in wild ungulates (Lavin, 2012). Grasses have higher level of silica, which increases tooth wear (McNaughton \& Georgiadis, 1986) and reduce fiber digestive ability (Robbins, 1993). Thirdly, T. quadricornis's small body size encourages it to be a browser (Shipley, 1999) as small animals need more energy per unit body weight to fuel a higher mass-specific metabolism, resulting in a high energy yield per gram of food consumed (Peters, 1986; Robbins, 1993). Small ruminants are therefore better suited for extracting energy from browser cell material (dicot plants) with smaller stomachs, whereas large-sized animals are better suited for high-fiber grasses with large sized gastrointestinal tract (Demment \& Van Soest, 1985). Fourthly, our previous study (Meghwal et al., 2018) reported that $T$. quadricornis shows association with southern plains gray langur (S. dussumieri) in the study area, providing additional foraging opportunities. The study recorded that $T$. quadricornis gleans four plant parts (flowers, pods, fruits, and leaves) dropped by $S$. dussumieri from 13 different tree species (Meghwal et al., 2018).

Tetracerus quadricornis showed seasonal variations in consumption of different plant categories and plant parts. The highest number of plants in the diet was from Fabaceae and Poaceae. This may

Table 4 A comparison of browse-grass ratio in diet of four-horned antelope (Tetracerus quadricornis) in different conditions and forest types

\begin{tabular}{|c|c|c|c|c|c|c|c|c|}
\hline Study Area & Study period & $\begin{array}{l}\text { Field } \\
\text { condition }\end{array}$ & Type of forest & Method & Browse ratio (\%) & $\begin{array}{l}\text { Grass ratio } \\
(\%)\end{array}$ & $\begin{array}{l}\text { Unidentified } \\
\text { (\%) }\end{array}$ & Reference \\
\hline Nepal & $\begin{array}{l}\text { Dec 2015- } \\
\text { Jan } 2016\end{array}$ & Wild & Dry deciduous forest & MHP & 66.36 & 29.25 & 4.4 & Oli et al., 2018 \\
\hline Nepal & 2012-2013 & Wild & $\begin{array}{l}\text { Grassland and } \\
\text { Himalayan } \\
\text { sub-tropical } \\
\text { broadleaved } \\
\text { forests }\end{array}$ & $\mathrm{MHP}$ & 78.03 & 21.97 & & Kunwar et al., 2016 \\
\hline South India & $\begin{array}{l}\text { Sept 1998- } \\
\text { Feb } 1999\end{array}$ & Wild & $\begin{array}{l}\text { Mix of tropical } \\
\text { dry thorn, dry } \\
\text { deciduous, moist } \\
\text { deciduous forests } \\
\text { with grasslands }\end{array}$ & MHP & 23.3 & 28.6 & 48 & Baskaran et al., 2011 \\
\hline $\begin{array}{l}\text { Van Vihar } \\
\text { National Park } \\
\text { cum Zoo, India }\end{array}$ & Oct 2002 & Captive & & CE & 100 & 0 & & Sharma et al., 2009 \\
\hline Western India & $\begin{array}{l}\text { April } 2014 \text { to } \\
\text { March } 2016\end{array}$ & Wild & $\begin{array}{l}\text { Tropical dry } \\
\text { deciduous forests }\end{array}$ & DO & 83.08 & 16.92 & & Present study \\
\hline
\end{tabular}


be due to their high availability in the region, whereas the variability in the use of plant parts may be related with local plant phenology (Koli et al., 2013) and nutritional content. Most of the trees are flowering and fruiting in India's tropical deciduous forests during the summer season (Singh \& Kushwaha, 2006) as well as in the study area shortly after winter departure (Chhangani, 2004; Sharma, 2007). Therefore, a high proportion of fruits in the T. quadricornis diet during the summer could be due to higher flowering and fruiting of most trees this season (Chhangani, 2004; Singh \& Kushwaha, 2006). Semnopithecus dussumieri's falling fruit activity could also increase fruit consumption (Meghwal et al., 2018). This proportion is subsequently decreased in monsoon and winter, although few species such as Mitragyna parviflora and Albizia odoratissima show flowering during the monsoon season, while several species of tree such as the genus Ficus show flowering and fruiting all year round. Plant species differ in protein and fiber content and may affect digestibility (Klaus-Hugi, Klaus, Schmid, \& Konig, 1999) and food choice (Shipley, 1999). Intake of protein increasing digestibility but in case of fiber, it is contrary. In our study, T. quadricornis grass intake increased during the monsoon season and ultimately increased grass account in the browse-grass ratio (59.09-40.91\%). Rains promote new grass growth, and intercalary meristem growth of grasses is found to be more nutritious than apical growth of browse (Jarman, 1974; Kunwar et al., 2016), while winter and summer retard the growth of grasses due to low moisture and make them less nutritious (Sukumar, 1989).

On the basis of our findings, we recommend conservation and encouragement of natural plant regeneration, particularly in Aristida adscensionis, Dendrocalamus strictus, Dichrostachys cinerea, Acacia leucophloea, Butea monosperma, Helicteres isora, Ziziphus nummularia, and Ziziphus xylopyrus which have contributed most to the diet of T. quadricornis (Table 2) in all three sanctuaries, mainly in those areas which support a healthy population of the species. The A. adscensionis is one of this area's pioneer grass species, but vulnerable to seasonal forest fire (from March to June; summer season) (Krishna \& Reddy, 2012). Early planning, construction, and maintenance of fire lines inside and around its distribution patches would help protect those areas prior to the timing of the forest fire. Planting could only be considered only after this fire season. Young leaves of D. strictus are consumed by $T$. quadricornis. This plant species could therefore be planted on the shore beds of rivers and channels, where moisture regime found better. Dichrostachys cinerea should be protected from fire hazard and its number could be increased by seed pallet broadcasting and seed notching methods. Butea monosperma contributed its various parts to the $T$. quadricornis diet. Sometimes, the tribal dugout its roots to make ropes and to make brushes for white wash on buildings. Moreover, these trees are also damaged by gum collectors (Per. Obser.). In order to preserve them, an effective monitoring of these activities is required. This species grows faster in the foothills; hence, its number can be increased by notching its seeds in these areas. Degraded areas of all three sanctuaries are colonized by A. leucophloea (Per. Obser.). Goat browsing should be controlled to reduce competition between T. quadricornis and domestic animals in these areas. In the foothills, $Z$. nummularia may be increased by means of seed broad casting and notching methods, while seed notching on hill slopes is a more suitable method for $Z$. xylopyrus. When $Z$. nummularia becomes tree, half of them should be coppiced and the pollarded stems 0.5 to $1.5 \mathrm{~m}$ in length should be left behind. As this species has a good regeneration capacity (Kar, 2006), new flush branches will provide plenty of leaves for T. quadricornis. The overall recommendations mentioned above should not only be made within the sanctuaries, but should be extended outside their boundaries so that the T. quadricornis spillover population can be protected in the future.

\section{Conclusions}

Overall, T. quadricornis was found to use more browse species than grasses in the study area with seasonal variation in diet. Trees contributed to a large proportion of the diet throughout the year. Grass contribution increased in diet during the monsoon season, likely due to its higher abundance. High fruit content in the summer diet may have been related with local plant phenology. The $S$. dussumieri association also provides additional benefits in feeding strategy and increased browse ratio in $T$. quadricornis diet.

On the basis of our findings from this study, we recommend conservation and encouragement of natural plant regeneration, in particular Aristida adscensionis, Dendrocalamus strictus, Dichrostachys cinerea, Acacia leucophloea, Butea monosperma, Helicteres isora, Ziziphus nummularia, and Ziziphus xylopyrus which have contributed most to the T. quadricornis diet (Table 2) in all three sanctuaries. Seasonal forest fire is a serious problem in the study area (Krishna \& Reddy, 2012). The fire management plans would help to protect these areas prior to this timing. Effective monitoring is also required to minimize illegal human interference and livestock grazing. 


\section{Appendix}

Table 5 Seasonal composition of Four-horned Antelope (T. quadricornis) diet in the tropical deciduous forest of southern Rajasthan, India ( $L=$ leaves, $B=$ buds, $T=$ twigs, $F L=$ flower, $F F=f l e s h y$ fruit, $D F=D r y$ fruit/pod). Data is presented in number of feeding records (percentage)

\begin{tabular}{|c|c|c|c|c|c|c|c|}
\hline \multirow{2}{*}{$\begin{array}{l}\text { Plant } \\
\text { category }\end{array}$} & \multirow[t]{2}{*}{ Family } & \multirow[t]{2}{*}{ Species } & \multirow{2}{*}{$\begin{array}{l}\text { Food } \\
\text { item }\end{array}$} & \multirow{2}{*}{$\begin{array}{l}\text { Feeding } \\
\text { record } \\
\text { (\%) }\end{array}$} & \multicolumn{3}{|c|}{ Feeding records per season (\%) } \\
\hline & & & & & Summer & Monsoon & Winter \\
\hline \multicolumn{4}{|c|}{ Total number of feeding records } & $532(100)$ & $242(45.5)$ & $119(22.4)$ & $171(32.1)$ \\
\hline \multirow[t]{13}{*}{ Monocot } & \multirow[t]{12}{*}{ Poaceae } & Aristida adscensionis* & L & 20(3.76) & $5(2.07)$ & $6(5.04)$ & $9(5.26)$ \\
\hline & & Cenchrus ciliaris * & $\mathrm{L}$ & $8(1.50)$ & - & $6(5.04)$ & $2(1.17)$ \\
\hline & & Cynodon dactylon* & $\mathrm{L}$ & 16(3.01) & $1(0.41)$ & $8(6.72)$ & $7(4.09)$ \\
\hline & & Digitaria ciliaris* & $\mathrm{L}$ & $4(0.75)$ & - & $4(3.36)$ & - \\
\hline & & Digitaria longiflora* & L & $5(0.94)$ & $5(2.07)$ & - & - \\
\hline & & Heteropogon contortus* & $\mathrm{L}$ & $8(1.5)$ & - & $8(6.72)$ & - \\
\hline & & Themeda triandra* & $\mathrm{L}$ & $12(2.26)$ & $2(0.83)$ & $7(5.88)$ & $3(1.75)$ \\
\hline & & Sehima nervosum* & L & $2(0.38)$ & $1(0.41)$ & $1(0.84)$ & \\
\hline & & Dichanthium annulatum* & $\mathrm{L}$ & $3(0.56)$ & $1(0.41)$ & $1(0.84)$ & $1(0.58)$ \\
\hline & & Eremopogon foveolatus* & L & $3(0.56)$ & $1(0.41)$ & $2(1.68)$ & - \\
\hline & & Apluda mutica* & L & $7(1.32)$ & $6(2.48)$ & $1(0.84)$ & - \\
\hline & & Dendrocalamus strictus ${ }^{\S}$ & L & 18(3.38) & $1(0.41)$ & - & 17(9.94) \\
\hline & Asparagaceae & Asparagus racemosus $^{\uparrow}$ & L & $1(0.19)$ & - & $1(0.84)$ & - \\
\hline \multirow[t]{26}{*}{ Dicot } & \multirow[t]{2}{*}{ Acanthaceae } & Justicia simplex & L & $1(0.19)$ & - & $1(0.84)$ & - \\
\hline & & Barleria cristata $^{\S}$ & L & $2(0.38)$ & $2(0.83)$ & - & - \\
\hline & Amaranthaceae & Achyranthes aspera $\downarrow$ & L & $2(0.38)$ & $2(0.83)$ & - & - \\
\hline & \multirow[t]{2}{*}{ Anacardiaceae } & Rhus mysorensis $^{\S}$ & $\mathrm{L}$ & $3(0.56)$ & $3(1.24)$ & - & - \\
\hline & & Lannea coromandelica ${ }^{\#}$ & $L, B, T, F F$ & 10(1.88) & $9(3.72)$ & - & $1(0.58)$ \\
\hline & Apocynaceae & Wrightia tinctoria\# & $\mathrm{L}, \mathrm{B}, \mathrm{T}, \mathrm{FF}$ & $14(2.63)$ & 10(4.13) & $1(0.84)$ & $3(1.75)$ \\
\hline & Boraginaceae & Cordia dichotoma\# & $L, B, T, F F$ & $4(0.75)$ & $2(0.83)$ & $1(0.84)$ & $1(0.58)$ \\
\hline & Burseraceae & Boswellia serrata\# & $L, B, T, F F$ & $4(0.75)$ & $4(1.65)$ & - & - \\
\hline & Capparaceae & Capparis sepiaria $^{\S}$ & $\mathrm{L}, \mathrm{FL}$ & $11(2.07)$ & $7(2.89)$ & $1(0.84)$ & $3(1.75)$ \\
\hline & \multirow[t]{3}{*}{ Combretaceae } & Anogeissus acuminata" & $L, B, T, F L$ & $16(3.01)$ & $4(1.65)$ & $3(2.52)$ & $9(5.26)$ \\
\hline & & Terminalia bellerica" & $L, B, T, F F$ & $6(1.13)$ & $4(1.65)$ & - & $2(1.17)$ \\
\hline & & Terminalia crenulata & $L, B, T, F F$ & $7(1.37)$ & $7(2.89)$ & - & - \\
\hline & Euphorbiaceae & Mallotus philippensis" & $\mathrm{L}, \mathrm{B}, \mathrm{T}, \mathrm{FF}$ & $2(0.38)$ & $2(0.83)$ & - & - \\
\hline & \multirow[t]{13}{*}{ Fabaceae } & Desmodium dichotomum $\downarrow$ & L & $2(0.38)$ & $2(0.83)$ & - & - \\
\hline & & Cassia pumila & L & $3(0.56)$ & $1(0.41)$ & - & $2(1.17)$ \\
\hline & & Dichrostachys cinerea ${ }^{\S}$ & $\mathrm{L}, \mathrm{DF}$ & 19(3.57) & $11(4.55)$ & $1(0.84)$ & $7(4.09)$ \\
\hline & & Acacia catechu ${ }^{\#}$ & $\mathrm{~L}, \mathrm{DF}$ & $15(2.82)$ & $7(2.89)$ & $3(2.52)$ & $5(2.92)$ \\
\hline & & Acacia leucophloea ${ }^{\#}$ & $\mathrm{~L}, \mathrm{DF}$ & $28(5.26)$ & 12(4.96) & $7(5.88)$ & $9(5.26)$ \\
\hline & & Acacia nilotica $^{\#}$ & $L, D F$ & $11(2.07)$ & $8(3.31)$ & - & $3(1.75)$ \\
\hline & & Acacia senegal ${ }^{\#}$ & $\mathrm{~L}, \mathrm{DF}$ & $8(1.5)$ & $6(2.48)$ & - & $2(1.17)$ \\
\hline & & Albizia lebbeck ${ }^{\#}$ & $L, D F$ & $6(1.13)$ & $3(1.24)$ & - & $3(1.75)$ \\
\hline & & Bauhinia racemosa & $\mathrm{L}, \mathrm{DF}$ & $13(2.44)$ & $4(1.65)$ & $9(7.56)$ & - \\
\hline & & Bauhinia variegata & $\mathrm{L}, \mathrm{B}, \mathrm{T}, \mathrm{DF}$ & $8(1.5)$ & $5(2.07)$ & - & $3(1.75)$ \\
\hline & & Butea monosperma ${ }^{\#}$ & $L, B, T, F L, D F$ & $21(3.95)$ & $9(3.72)$ & $5(4.09)$ & $7(4.09)$ \\
\hline & & Cassia fistula & $L, B, T$ & $9(1.69)$ & $2(0.83)$ & $2(1.68)$ & $5(2.92)$ \\
\hline & & Dalbergia sissoo" & $L, D F$ & $5(0.94)$ & $3(1.24)$ & - & $2(1.17)$ \\
\hline
\end{tabular}


Table 5 Seasonal composition of Four-horned Antelope (T. quadricornis) diet in the tropical deciduous forest of southern Rajasthan,

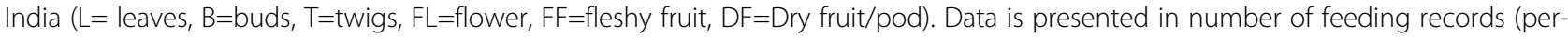
centage) (Continued)

\begin{tabular}{|c|c|c|c|c|c|c|c|}
\hline \multirow{2}{*}{$\begin{array}{l}\text { Plant } \\
\text { category }\end{array}$} & \multirow[t]{2}{*}{ Family } & \multirow[t]{2}{*}{ Species } & \multirow{2}{*}{$\begin{array}{l}\text { Food } \\
\text { item }\end{array}$} & \multirow{2}{*}{$\begin{array}{l}\text { Feeding } \\
\text { record } \\
\text { (\%) }\end{array}$} & \multicolumn{3}{|c|}{ Feeding records per season (\%) } \\
\hline & & & & & Summer & Monsoon & Winter \\
\hline & & Albizia odoratissima" & L,DF & $3(0.56)$ & $2(0.83)$ & - & $1(0.58)$ \\
\hline & & Pithecellobium dulce & $L$ & $6(1.13)$ & $4(1.65)$ & - & $2(1.17)$ \\
\hline & & Prosopis cinerariä & $L, D F$ & $7(1.32)$ & $5(2.07)$ & - & $2(1.17)$ \\
\hline & & Tamarindus indica & $L$ & $4(0.75)$ & $4(1.65)$ & - & - \\
\hline & Lamiaceae & Clerodendrum phlomidis ${ }^{\S}$ & $\mathrm{L}, \mathrm{FL}$ & $2(0.38)$ & $2(0.83)$ & - & - \\
\hline & Meliaceae & Soymida febrifuga\# & $L, B, T, F F$ & $2(0.38)$ & $1(0.41)$ & - & $1(0.58)$ \\
\hline & Malvaceae & Grewia hirsuta $^{\S}$ & $L, F F$ & $13(2.44)$ & $7(2.89)$ & $1(0.84)$ & $5(2.92)$ \\
\hline & & Helicteres isora ${ }^{\S}$ & $L, B, T, D F$ & $21(3.95)$ & 13(5.37) & - & $8(4.68)$ \\
\hline & & Bombax ceiba ${ }^{\#}$ & $L, B, T, F L$ & $5(0.94)$ & $5(2.07)$ & - & - \\
\hline & Moraceae & Ficus racemosa ${ }^{\#}$ & $L, B, T, F F$ & $15(2.82)$ & $10(4.13)$ & $2(1.68)$ & $3(1.75)$ \\
\hline & & Ficus religiosa ${ }^{\#}$ & $L, B, T, F F$ & $5(0.94)$ & $1(0.41)$ & - & $4(2.34)$ \\
\hline & Oleaceae & Nyctanthes arbor-tristis ${ }^{\S}$ & $\mathrm{L}$ & $4(0.75)$ & - & - & $4(2.34)$ \\
\hline & Phyllanthaceae & Bridelia retusa\# & $\mathrm{NL}, \mathrm{B}, \mathrm{T}$ & $1(0.19)$ & $1(0.41)$ & - & - \\
\hline & & Emblica officinalis" & L,FF & $6(1.13)$ & $3(1.24)$ & - & $3(1.75)$ \\
\hline & Rhamnaceae & Ziziphus nummularia & $\mathrm{L}, \mathrm{FF}$ & 18(3.38) & $1(0.41)$ & $8(6.72)$ & $9(5.26)$ \\
\hline & & Ziziphus glabrata\# & L,FF & $12(2.26)$ & - & $7(5.88)$ & $5(2.92)$ \\
\hline & & Ziziphus mauritiana\# & L,FF & $16(3.01)$ & $2(0.83)$ & $9(7.56)$ & $5(2.92)$ \\
\hline & & Ziziphus xylopyrus" & $L, F F$ & $21(3.95)$ & $5(2.07)$ & $10(8.4)$ & $6(3.51)$ \\
\hline & Rubiaceae & Haldina cordifolia\# & $L$ & $2(0.38)$ & $1(0.41)$ & - & $1(0.58)$ \\
\hline & & Hymenodictyon excelsum ${ }^{\#}$ & $L, B, T$ & $2(0.38)$ & $1(0.41)$ & - & $1(0.58)$ \\
\hline & & Mitragyna parvifolia ${ }^{\#}$ & $L, F F$ & $9(1.69)$ & $5(2.07)$ & $2(1.68)$ & $2(1.17)$ \\
\hline & Rutaceae & Aegle marmelos ${ }^{\#}$ & $L, B, T, F F$ & $7(1.32)$ & $4(1.65)$ & - & $3(1.75)$ \\
\hline & Salicaceae & Flacourtia indica & $L, B, T$ & $2(0.38)$ & $1(0.41)$ & $1(0.84)$ & - \\
\hline & Sapotaceae & Madhuca indica ${ }^{\#}$ & $\mathrm{FL}, \mathrm{FF}$ & $12(2.26)$ & $12(4.96)$ & - & -- \\
\hline
\end{tabular}

Growth forms: * ${ }^{2}$ rasses, ${ }^{\downarrow}$ Forbs, ${ }^{\uparrow}$ Climber, ${ }^{\S}$ Shrubs, ${ }^{\#}$ Tree

\section{Abbreviations}

IUCN: International Union for Conservation of Nature; WLS: Wildlife Sanctuary; SD: Standard deviation; L: Leaves; B: Buds; T: Twigs; FL: Flower; FF: Fleshy fruit; DF: Dry fruit/pod; MHP: Micro-histological photography; CE: Cafeteria experiment; DO: Direst observation

\section{Acknowledgements}

We thank Dr. Pankaj Sen for his help in fieldwork and Dr. Satish Kumar Sharma and Dr. K. S. Gopi Sundar for insightful suggestions and comments on the earlier draft. The authors declare that they have no conflict of interests.

\section{Authors' contributions}

Study planning: RM, CB, and VKK; fieldwork: RM; data analysis: RM and VKK; manuscript writing: VKK, with participation of RM and CB. All authors have read and approved the manuscript for publication.

\section{Funding}

Financial support received from the University Grants Commission (UGC), India, in the form of Rajiv Gandhi National Fellowship (RGNF) during research work is duly acknowledged.

\section{Availability of data and materials}

It is possible to request authors for the data used and analyzed during the current study.

\section{Ethics approval and consent to participate}

The study was conducted with due permission vides letter no. 3(01)tak-11/ PCCF/2010/687, dated 28 April 2014 by Department of Forests, Government of Rajasthan (India) is duly acknowledged.

\section{Consent for publication}

Not applicable.

\section{Competing interests}

The authors declare that they have no competing interests.

Received: 27 November 2019 Accepted: 18 September 2020 Published online: 25 September 2020

\section{References}

Altmann, J. (1974). Observational study of behaviour: Sampling methods. Behaviour, 49, 227-267.

Anthony, R. G., \& Smith, N. S. (1974). Comparison of rumen and fecal analysis to describe deer diets. Journal of Wildlife Management, 38, 535-540. 
Baskaran, N. (1998). Ranging and resource utilization by Asian elephant (Elephas maximus Linn.) in Nilgiri Biosphere Reserve, South India. Ph.D. Thesis, Bharathidasan University, Tiruchirapalli, India.

Baskaran, N., Kannan, V., Thiyagesan, K., \& Desai, A. A. (2011). Behavioural ecology of four-horned antelope (Tetracerus quadricornis De Blainville, 1816) in the tropical forests of southern India. Mammlian Biology, 76, 741-747.

Berwick, S. H. (1974). The community of wild ruminants in the Gir forest ecosystem, India. Ph. D. dissertation, University of Michigan, USA.

Champion, H. G., \& Seth, S. K. (1968). A revised survey of forest types of India. New Delhi: Government of India.

Chhangani, A. K. (2004). Flowering and fruiting phenology of plants of a dry deciduous forest in the Aravalli hills of Rajasthan, India. Indian Forester, 130, $771-784$

Demment, M. W., \& Van Soest, P. J. (1985). A nutritional explanation for body-size patterns of ruminant and nonruminant herbivores. The American Naturalist, $125,641-672$

FES, (2010a). Assessment of biodiversity in Sitamata Wildlife Sanctuary: A conservation perspective. Final Report, Foundation for Ecological Security, Gujarat, India.

FES, (2010b). Assessment of biodiversity in Kumbhalgarh Wildlife Sanctuary: A conservation perspective. Final Report, Foundation for Ecological Security, Gujarat, India.

FES, (2010c). Assessment of biodiversity in Phulwari-ki-nal Wildlife Sanctuary: A conservation perspective. Final Report, Foundation for Ecological Security, Gujarat, India.

Jarman, P. J. (1974). The social organization of antelope in relation to their ecology. Behaviour, 48, 215-267.

Kar, A. (2006). Formation and morphology of shrub-coppice dunes in the Thar Desert. The Deccan Geographer, 44, 51-64.

Klaus-Hugi, C., Klaus, G., Schmid, B., \& Konig, B. (1999). Feeding ecology of large social antelope in the rainforest. Oecologica, 119, 81-90.

Koli, V. K., \& Bhatnagar, C. (2011). Mammalian fauna in Sitamata Wildlife Sanctuary, Rajasthan. Geobios, 38, 157-160.

Koli, V. K., Bhatnagar, C., \& Sharma, S. K. (2013). Food habits of Indian giant flying squirrel (Petaurista philippensis Elliot) in tropical deciduous forest, Rajasthan, India. Mammal Study, 38, 251-259.

Korschgen, L. J. (1971). Procedure for food-habit analysis. In R. H. Giles (Ed.), Wildlife management Techniques, (pp. 233-250). Washington, DC: The Wildlife Society.

Krishna, P. H., \& Reddy, C. S. (2012). Assessment of increasing threat of forest fires in Rajasthan, India using multi-temporal remote sensing data (2005-2010). Current Science, 102, 1288-1297.

Krishna, Y. C., Clyne, P. J., Krishnaswamy, J., \& Kumar, N. S. (2009). Distribution and ecology review of the four horned antelope, Tetracerus quadricornis. Mammalia, 73, 1-6.

Krishna, Y. C., Krishnaswamy, J., \& Kumar, N. S. (2008). Habitat factors affecting site occupancy and relative abundance of four-horned antelope. Journal of Zoology, 276(1), 63-70.

Kunwar, A., Gaire, R., Pokharel, K. P., Baral, S., \& Thapa, T. B. (2016). Diet of the fourhorned antelope Tetracerus quadricornis (De Blainville, 1816) in the Churia hills of Nepal. Journal of Threatened Taxa, 8, 8745-8755.

Lavin, S. R. (2012). Plant phenolics and their potential role in mitigating iron overload disorder in wild animals. Journal of Zoo and Wildlife Medicine, 43 74-82.

Leslie, D. M., \& Sharma, K. (2009). Tetracerus quadricornis (Aritiodactyla: Bovidae). Mammal Species, 843, 1-11.

Lukhele, M. S., \& Van Ryssen, J. B. J. (2003). The chemical composition and potential nutritive value of the foliage of four subtropical tree species in southern Africa for ruminants. South African Journal of Animal Science, 33, $132-141$

Mallon, D. P. (2008). Tetracerus quadricornis, The IUCN Red List of Threatened Species, e.T21661A9307713 (). https://doi.org/10.2305/IUCN.UK.2008.RLTS T21661A9307713.en Accessed 08 June 2017.

Mbatha, K. R., \& Bakare, A. G. (2018). Browse silage as potential feed for captive wild ungulates in South Africa: A review. Animal Nutrition, 4, 1-10.

McNaughton, S. J., \& Georgiadis, N. J. (1986). Ecology of African grazing and browsing mammals. Annual Review of Ecology, Evolution, and Systematics, 17, 39-65.

Meghwal, R., Bhatnagar, C., \& Koli, V. K. (2018). Activity and social behavior of four-horned antelope (Tetracerus quadricornis de Blainville, 1816) in tropical deciduous forests of Aravalli Mountain range, western India. Folia Zoologica, $67,22-31$.

Meghwal, R., Sen, P. K., \& Bhatnagar, C. (2014). Habitat preference of four-horned antelope (Chowsingha), Tetracerus quadricornis in Kumbhalgarh Wildlife Sanctuary, Rajasthan. Ambient Science, 3, 38-42.

Ngwa, T. A., Nsahlai, I. V., \& lji, P. A. (2004). Ensilage as a means of reducing the concentration of cyanogenic glycosides in the pods of Acacia sieberiana and the effect of additives on silage quality. Journal of the Science of Food and Agriculture, 84, 521-529.

Oli, C. B., Panthi, S., Subedi, N., Ale, G., Pant, G., Khanal, G., \& Bhattarai, S. (2018). Dry season diet composition of four-horned antelope Tetracerus quadricornis in tropical dry deciduous forests, Nepal. PeerJ, 6, e5102.

Peters, R. H. (1986). The ecological implication of body size. Cambridge: Cambridge University Press.

Pokharel, K. P., Ludwig, T., \& Storch, I. (2016). Predicting potential distribution of poorly known species with small database: the case of four-horned antelope Tetracerus quadricornis on the Indian subcontinent. Ecology and Evolution, 6, 2297-2307.

Prater, S. H. (1980). The book of Indian animals. Bombay: Bombay Natural History Society/Oxford University Press.

Robbins, C. T. (1993). Wildlife feeding and nutrition. San Diego: Academic Press, Inc.

Robbins, C. T., Spalinger, D. E., \& Van Hoven, W. (1995). Adaptation of ruminants to browse and grass diets: Are anatomical-based browser-grazer interpretations valid? Oecologia, 103(2), 208-213.

Robbins, P. F., Chhangani, A. K., Rice, J., Trigosa, E., \& Mohnot, S. M. (2007). Enforcement authority and vegetation change at Kumbhalgarh wildlife Sanctuary, Rajasthan, India. Environment Management, 40, 365-378.

Sharma, K., Chundawat, R. S., Gruisen, J. V., \& Rahmani, A. R. (2013). Understanding the patchy distribution of four-horned antelope Tetracerus quadricornis in a tropical dry deciduous forest in central India. Journal of Tropical Ecology, 30, 45-54.

Sharma, K., Rahmani, A. R., \& Chundawat, R. S. (2009). Natural history observation of the four-horned antelope Tetracerus quadricornis. Journal of the Bombay Natural History Society, 106, 72-82.

Sharma, S. K. (2007). Study of biodiversity and ethnobiology of Phulwari Wildife Sanctuary, Udaipur (Rajasthan). Ph. D. Thesis, Mohanlal Sukhadia University Udaipur, Rajasthan, India.

Shipley, L. A. (1999). Grazers and browsers: How digestive morphology affects diet selection. In K. L. Launchabugh, K. D. Sanders, \& J. C. Mosley (Eds.), Grazing behavior of livestock and wildlife, (pp. 20-27) Idaho Forest, Wildlife and range expeditions station bulletin, University of Idaho, Moscow.

Singh, K. P., \& Kushwaha, C. P. (2006). Diversity of flowering and fruiting phenology of trees in a tropical deciduous forest in India. Annals of Botany, 97, 265-276.

Sukumar, R. (1989). The Asian elephant: Ecology and management. Cambridge: Cambridge University Press.

\section{Publisher's Note}

Springer Nature remains neutral with regard to jurisdictional claims in published maps and institutional affiliations.

\section{Submit your manuscript to a SpringerOpen ${ }^{\circ}$ journal and benefit from:}

- Convenient online submission

- Rigorous peer review

- Open access: articles freely available online

- High visibility within the field

- Retaining the copyright to your article

Submit your next manuscript at $>$ springeropen.com 